\title{
METAMORPHOSES OF MODERN RUSSIAN EDUCATION
}

\author{
Babaeva A.V. ${ }^{1}$, Borisova A.A ${ }^{2}$ \\ ${ }^{1}$ Doctor of philosophy Sciences, Professor Voronezh State University of Engineering Technologies, \\ Revolution Avenue,19, Voronezh, Russia, E-mail: annabab1@yandex.ru \\ ${ }^{2}$ Candidate of Historical Sciences, Associate Professor, Voronezh State University of Engineering \\ Technologies, Revolution Avenue,19, Voronezh, Russia, E-mail: allaborisova@yandex.ru
}

\begin{abstract}
The article discusses the trends and prospects of modern Russian education. Special attention is paid to the implementation of UNESCO's ideas highlighted in the 2000 report.

Distortions in the Russian educational process are highlighted. New methods are shown, the use of which can help in the implementation of a new educational paradigm.
\end{abstract}

Keywords: education, innovation, digital society, paradigm, methods

\section{INTRODUCTION}

At the beginning of the XXI century, UNESCO in the world report on education identified the main vectors of development of modern education. There were 4 basic principles of "education of the future": "learn to live, learn to learn, learn to do and learn to coexist» $[1$, p. 7$]$.

As a result, the transition to a new paradigm of education was announced. Any transition to a new, innovative process is painfully perceived by society. 20 years have passed since the proclamation of the beginning of the formation of a new educational paradigm, but now many people perceive the learning process as a simple transfer of knowledge.

Within the framework of the classical paradigm, the idea prevailed that the student -- «tabula rasa», on which the caregiver can write anything. This principle has been the main one in the process of European education for several centuries. Within the framework of the classical educational paradigm, the main emphasis was placed on the perception and memorization of ready-made educational information by students, which carries knowledge about the past, about situations of theoretical or practical action that have already been realized and require their understanding As J.A.. Komensky wrote, it is unwise to tell the student something contradictory at the very beginning of the lesson, i.e. to arouse doubts about what should be studied, it is necessary to take care that students do not receive any other books except those that are accepted in the corresponding class and are sources of wisdom, virtue and piety. The traditional educational paradigm was a kind of reflection of the labor organization of early industrial production, for the service of which people must EN masse acquire knowledge and develop skills that are necessary for work. In General, it can be noted that the classical educational paradigm prevailed in the period of time when the educational and labor processes were separated. $\mathrm{n}$ the beginning, it was necessary to acquire knowledge, skills, and only then implement them. Moreover, the knowledge gained was sufficient for the entire period of a person's working life.

\section{METHODOLOGY}

The theoretical and methodological basis of the study are the philosophical-anthropological and historicalcultural principles, as well as a systematic approach.

The study is empirical in nature, since it studies phenomena that need to be more deeply understood, systematized and structured. 
The research presented in this paper is based on a synthesis of the listed approaches and develops a philosophical and anthropological direction.

\section{DISCUSSION}

Post-industrial society and, especially, information culture, give a new quality of public life. They have led to a change in many existing socio-economic, political and spiritual ideas, and have introduced qualitatively new features into the way of life of a person. The modern world requires changes in both the activity of the subject teacher, who personifies the lesson, and the principle of uniting students, which determines classes. The possibility of a significant transformation of the space of pedagogical action is also inherent in the emergence of new technical means of storing and transmitting information, the introduction of which in the educational process fundamentally changes the position of each of its participants. It is clear that the education system must change its fundamental principles. At the beginning of the XXI century, the Russian teacher V. V. Guzeeva noted: "The subject of our legitimate pride - a large amount of knowledge-has almost lost its value in the changed world, as any information has become easily accessible, and its volume is growing rapidly. It is not the knowledge itself that becomes necessary, but the knowledge of where and how to apply it. But even more important is the knowledge of how to extract, integrate, or create new information» [2, p.72].

As a result, a new Federal state standard of education was adopted in Russian society. The adoption of the new GEF approved the transition from the traditional pedagogical paradigm of the type of knowledge to the paradigm of formation and development of interdisciplinary skills, where the main task of the educational system is to teach children not only learn, but to live in peace, to build up a communicative relationship, to implement the management principles of the self.

So, high goals were proclaimed and new tasks were set. What has changed in Russian education in recent decades? The analysis of the Ministry's documents and regional reports forms an idea of the brilliant results achieved. Familiarity with the realities-makes you wonder if everything is so successful or if a glossy picture has been created yet, behind which the reality is not always pretty.

The search for new forms of architecture of the educational space led to the rejection of the knowledge model and its replacement by the process of forming universal educational actions in schools and competencies in universities. At first glance, this is an important innovation that should have allowed us to form motivation for learning and self-learning. This model was supposed to help a person to assert a vocation to work, i.e. to create something himself, to invent new ways of working, and not only to use the learned techniques of work and old knowledge.

As a result, the rejection of knowledge that needs to be transferred in the learning process has led to the fact that universal learning activities and competencies without knowledge "hung in the air". You can learn how to make beautiful presentations, make presentations, and participate in game competitions. In General, learning is fun. In this active game reality, which began to take up a large amount of time in the learning process, we forgot that at one time V. A. Sukhomlinsky spoke about the inadmissibility of "concerts" in the classroom, considering it pedagogical ignorance. He emphasized: "An important task of the school is to educate a person with inquisitive, creative, searching thoughts» [3, p 147].

As a result, the desire to strengthen cognitive interests only at the visual-figurative level led to a decrease in the level of education.

Yes, changes are necessary, but by introducing innovations, we must not lose the foundations on which the entire system is built. You can argue that it is impossible to know everything, there is an Internet where you can find everything. But without knowledge, all these helper tools lose their meaning. Information is never equal to knowledge. "Information is not yet knowledge, that to acquire the latter it is necessary to make efforts, show attention, will and perseverance» [1, p.18]. And even if we accept their equality, there remains the requirement of critical evaluation. The lack of knowledge does not allow you to critically evaluate, allowing you to believe absolutely any fake news and fake information. And somehow it was completely forgotten that a UNESCO report 20 years ago noted: "given the rapid changes associated with scientific progress and new forms of economic and social activity, it is necessary to combine a fairly broad General cultural knowledge, with the possibility of deep comprehension of a limited number of disciplines. The General cultural level is in some ways a passport to continuing education, as it instills a taste for education, as well as being its Foundation, necessary for lifelong learning» [1, p. 13].

Whether we want to or not, the traditional paradigm has become a "worn-out God " (Rilke). But in the process of total denial, the accumulated important experience is lost. We have forgotten that education must 
constantly adapt to these changes in society, without neglecting the transfer of achievements, basic knowledge, and the fruits of human experience» [1, p. 14].

The speed of the digital society is pushing the non-knowledgeable to the sidelines. In the modern world, indeed, people are needed who are ready for constant retraining. In modern Russian education, we are faced with an "inverted" model. The "bad infinity" of advanced training and retraining has replaced reality. There is a situation that was clearly expressed in his time by A. S. Pushkin in Eugene Onegin: "We all learned a little bit. Something and somehow". And, so far, the last part wins - "somehow".

The complexity of the formation of a new model of education in modern Russian society is associated with the existing "gap" between generations. Those who teach and those who are taught do not understand each other. The dynamics of the world gave rise to an active language transformation. Many concepts used in speech by people of older generations do not carry any semantic load for "generation Z". The ability to understand each other becomes a serious problem. Distortions in the process of understanding led to illogicality, substitution of concepts and "blurring" of the meanings of words and terms. We stopped reacting to stupidity, violation of logic, nonsense. We are not surprised by ridiculous abbreviations, names that not only do not reflect the essence, but are anomalous. I recall a mythological image of the Trickster when we see the name "Russian language for the Russian" textbook "Italian without words", etc. Words ceased to Express events, "lightness of being", reckless handling of words-became the norm of life. "There was an erosion of the word when the words decayed or evaporated» [4, p. 97]

In addition, understanding is the ability not only to process rationally, to realize, but also to experience emotionally. The modern world is developing emotional deafness. In a world where every second something happens and "you have to make it..." emotional experiences become a luxury that does not have time and energy.

This is where education could help. But... it is still unclear what and how to teach, so that it is not an appearance of education, but a real process. How to teach those who not only speak a different language, but also perceive information differently? The Internet browser has created a new form of "reading", in which users no longer read something online, but simply browse sites.

Instead of reading from left to right, up and down, as has been done for centuries, we are now increasingly looking at headings and subheadings, as well as various markers and information that is highlighted by the publication in a special font or color. Understanding and attention in such a reading is certainly compromised - because instead of a complete picture, the reader receives only a part of it, which at the same time can also be misinterpreted by them.

The world of words-thoughts is replaced by the world of signs-pictures. In response to this, there are "textbooks - comics", "game tasks". The educational space is actively filled with the game component. And the understanding goes away that the learning process is a work that requires strong-willed efforts.

\section{RESULTS}

The new has become a part of our world. It is necessary to try to see in this new not only positive or negative, but to understand that everything is interconnected. The new education system should help the formation of a person, teach him to resist frozen traditions, critically evaluate any information. In modern pedagogy, the following methods are actively used, which take into account the specifics of modern children and young people. Let's try to choose among them those that may give us a chance to get closer to understanding each other.

- Flipped learning - this is a pedagogical model in which the typical presentation of lectures and the organization of homework are presented in reverse. This model has been used since 2007. The essence of this model is that students watch short video lectures at home, and in the classroom all the time is devoted to discussing and / or practical application of the knowledge gained.

- Micro-training. By which we understand the fragmentation of information into small parts. It is easier to work with a small amount of information. And if you consider that many courses are viewed on mobile devices today, then small videos and texts on 3-5 of the mobile screen are just the volume that does not cause difficulties for users.

\section{- Peer-to-peer, (peer-to-peer learning)}

This model is built on the principle of "peer-to-peer" and, unlike traditional models, involves mutual training of participants. When a student can act as a teacher for their classmates. 
- Smart- training, first of all, should form the ability to set consistent goals, find and critically evaluate additional information.

- Gamification in the education system. In modern research, the term "kidults and iPad generation" is increasingly appearing for which the game is the norm of life. [5].

The game becomes the dominant form of education and social life. It is the teacher who must create the conditions for the inclusion of the game component in the fabric of the educational process. The difficulty lies in the fact that it is necessary to find a "middle ground" between the game and the complexity of the learning process itself.

\section{CONCLUSION}

The round of devaluation, breaking, rejection of education will necessarily be replaced by a round of significance, value. Already today it is necessary to prepare the basis for the beginning of this process.

The teacher must learn to transform his subject, taking into account the reality in which we find ourselves. On the other hand, it is necessary to show that any subject can help in the formation of a person, the process of self-development and self-improvement. The modern world "removes" the differentiation between objects. Now we are all "in the same boat". And success or failure in the education system depends on everyone involved in this process.

\section{REFERENCE LIST}

World report on education 2000: the Right to education: towards education for all throughout life. - Moscow: MAGISTER-PRESS / UNESCO, 2000. - 192 p.

Guzeeva V.V (2006). Effective educational technologies. - M.: research Institute of school technologies. - 250 p. . (in Russ).

Sukhomlinsky. V.A(1979-1981) Selected pedagogical works: in 3 volumes / [compiled by O. S. Bogdanova, V. Z. smal; editorial Board: N. P. Kuzin (chief editor), etc. - Moscow: Pedagogika, 1979-1981. Vol. 1. . (in Russ).

Sergeev A.V. , Sokolov B.G.(2015) The Gap of everyday life: a dialogue of 300 cups of coffee and 3 blocks of cigarettes.- St. Petersburg: "Alethea", 257 p. . (in Russ).

«Trends in modern education». (In Russ.) (2018) [Electronic resource]. Mode of access: https://edmarket.ru/blog/top-trends-of-e-learning

Ershov B. A., Semenkova E. V. (2016) The consequences of the collapse of the Soviet Union. International Journal of Humanities and Natural Sciences. № 3. Pp. 20-22. (in Russ).

Ershov B.A. (2010) The Russian Orthodox Church and secular power in the Voronezh province in the XIX early XX centuries. GOU VPO "Voronezh State Technical University". Voronezh. 167 p.

Ershov B.A. (2010) The system of spiritual education in Voronezh province in the 19th century. Education and Society. №. 5 (64). Pp. 105-108.

Ershov B.A., Fursov V.N. (2018) The Russian Church in the State Mechanism of Russia. Bulletin SocialEconomic and Humanitarian Research. № 1. Pp. 32-37.

Ershov B.A., Perevozchikova L.S., Romanova E.V. (2019) Globalization and Intensification of Spiritual Values in Russia in the Philosophical Aspect. 6th International Conference on Education and Social Sciences Abstracts \& Proceedings. Pp. 208-212.

Ershov B.A., Volkova E.A., Frolova E.V., Volkov N.M., Pletnev V.I. (2019) The Revolution of 1905-1907. in Russia: results and consequences. 6th International Conference on Education and Social Sciences. Abstracts \& Proceedings. Pp. 213-220. (in Engl).

Romanova E.V., Perevozchikova L.S., Ershov B.A. (2017) The Lifestyle of the Human Being in the Information Society. 3rd International Conference on Advances in Education and Social Sciences Proceedings of ADVED Pp. 950-954. 